\title{
Early Christian Communities Between Ideal and Reality
}

\author{
Ed. by Mark Grundeken and Joseph Verheyden
}

[Frühchristliche Gemeinden zwischen Idealbild und Realität.]

Veröffentlicht auf Englisch.

Die Autoren des vorliegenden Bandes untersuchen die Vorstellung von der »christlichen Gemeinde« in den Schriften der Apostolischen Väter. Sie behandeln verschiedene Aspekte, wie die Bemühungen, die Gemeinde zu organisieren, eine sakramentale und rituelle Praxis zu entwickeln, eine Identität gegenüber Außenstehenden zu schaffen, zu missionieren und nach einer besseren Gemeinschaft zu streben. Die Wechselbeziehung zwischen Idealbild und Realität in den Quellen bietet zuverlässige Informationen bezüglich des alltäglichen Lebens und konkreter Umstände in frühchristlichen Gemeinden gegen Ende des ersten und in der ersten Hälfte des zweiten Jahrhunderts. Mit Beiträgen von: Paul Foster, Mark Grundeken, Clayton N. Jefford, James Kelhoffer, Taras Khomych, John S. Kloppenborg, Judith Lieu, Andreas Lindemann, Harry O. Maier, Tobias Nicklas, James Carleton Paget, Joseph Verheyden

\section{Inhaltsübersicht}

Joseph Verheyden/Mark Grundeken: Introduction - Andreas Lindemann: Sakramentale Praxis in Gemeinden des 2. Jahrhunderts - Clayton N. Jefford: The Didache and Eucharist: Signs of Community? - Taras Khomych: From Glorious Past to Miserable Present: First Clement on the Organisation of the Corinthian Community - John S. Kloppenborg: Pneumatic Democracy and the Conflict in 1 Clement - James Kelhoffer: If Second Clement Really Were a "Sermon, "How Would We Know, and Why Would We Care? Prolegomena to Analyses of the Writing's Genre and Community - Paul Foster: Christ and the Apostles in the Epistles of Ignatius of Antioch - Mark Grundeken: Baptism and Metanoia in the Shepherd of Hermas - Harry O. Maier: From Material Place to Imagined Space: Emergent Christian Community as Thirdspace in the Shepherd of Hermas Judith Lieu: From Us But Not Of Us? Moving the Boundaries of the Community - James Carleton Paget: Barnabas and the Outsiders: Jews and Their World in the Epistle of Barnabas - Tobias Nicklas: Identitätsbildung durch Konstruktion der »Anderen«: Die Schrift Ad Diognetum

ISBN 978-3-16-153509-3

DOI 10.1628/978-3-16-153509-3

eBook PDF 129,00€

ISBN 978-3-16-152670-1

Leinen $129,00 €$

Mark Grundeken Geboren 1984; 2002-08 Studium der Theologie und Religionswissenschaft in Leiden, Oxford und Leuven; 2013 Dr. theol. (KU Leuven); 2019 Dr. theol. habil. und PD (ALU Freiburg); derzeit Akademischer Rat und Privatdozent mit einer venia legendi für die Fachgebiete »Neues Testament« und »Frühchristliche Literatur « am Arbeitsbereich Neutestamentliche Literatur und Exegese an der Albert-Ludwigs-Universität Freiburg im Breisgau; 2020 mit dem Manfred-Fuchs-Preis der Heidelberger Akademie der Wissenschaften ausgezeichnet.

Joseph Verheyden is Professor of New Testament Studies in the Faculty of Theology and Religious Studies at the KU Leuven. https://orcid.org/0000-0002-8646-5233

Jetzt bestellen:

https://mohrsiebeck.com/buch/early-christian-communities-between-ideal-and-reality-9783161535093?no_cache=1 order@mohrsiebeck.com

Telefon: +49 (0)7071-923-17

Telefax: $+49(0) 7071-51104$ 